Journal of Extension Education

Vol. 28 No. 2, 2016

\title{
Farmers' Perception on Innovations in Technology Dissemination (ITD) Methods
}

\author{
Namitha Reghunath ${ }^{1}$ and N. Kishore Kumar ${ }^{2}$
}

\begin{abstract}
Innovations in Technology Dissemination (ITD) is a part of Agricultural extension system, concerned with transmitting information and knowledge of important agricultural technology from research to farmer. The present study was conducted in Kannur district of Kerala to identify the perception of farmers on ITD methods implemented by different agricultural institutions in Kannur district with special reference to Kannur Krishi Vigyan Kendra (KVK). Thirty farmers each from four selected grama panchayats (Ezhome, Kankol- Alapadamba, Kadannapalli- Panapuzha and Mayyil) of Kannur were identified using simple random sampling and a total of one hundred and twenty respondents were included in the study. A well-structured interview schedule was used for collecting the data from the respondents. The data were tabulated and inferences were drawn after appropriate statistical analysis. Majority of the farmers had medium level of perception on ITD methods followed by low level.
\end{abstract}

Keywords : ITD, KVK, Personal interview, Perception, Kerala, Farmer.

\section{INTRODUCTION}

Most of the farmers in India are small and marginal farmers with less land holding and poor in idea about new technologies. Extension in many countries has come to encompass a wide range of activities in both the public and private sectors, yet the exchange of information continues to be the primary focus of all extension activities. Earlier, agricultural extension in India was considered to be the monopoly of the public sector but with the wide range of demands for agricultural technology in changing scenarios there is a growing recognition that public extension by itself cannot meet the specific needs of various regions and different classes of farmers. This has lead to the emergence of pluralistic system, that include public, private and all other agencies which serve as knowledge or information agents that facilitate mutually meaningful and equitable knowledge based transactions among agricultural researchers, trainers and primary producers. The major activities of public extension system

1- P.G. Scholar and 2- Professor, Department of Agriculture Extension, College of Agriculture, Kerala Agricultural University, Vellayani, Kerala. 
at the district level are assessment, refinement and demonstration of technology / products through a network of Krishi Vigyan Kendras (KVKs), the departments of agriculture, Agricultural Technology Management Agency (ATMA) and Agricultural Technology Information Centres (ATIC) established under Indian Council of Agricultural Research (ICAR) institutes, State Agricultural Universities (SAUs) etc. Along with public extension agencies Non-Governmental Organizations (NGOs) play an important role in technology dissemination.

Innovations in Technology Dissemination (ITD) is part of the Agricultural extension system which is primarily concerned with transmitting information and knowledge of important agricultural technology. Kannur KVK had introduced a variety of innovations for technology dissemination and in 2009 it bagged the national best KVK award among the 589 KVKs in the country. The ITD methods implemented by the KVK include Compact Area Group Approach (CAGA), farmers science congress, farmers science museum, tele cine drama (Thengukalude Nilavili), NABARDKVK farmers club, training programmes for farm entrepreneurs, KVK mall, SBI KVK loan window, formation of mussel farmers club, participatory production of planting materials and vegetable seeds, formation of farmer producer organizations, agro- bio pharmacy, release of video and multimedia CDs related to various practices, farmers field school and distributing various brochures and publications.

\section{METHODOLOGY}

The study was conducted in Kannur district with special reference to Kannur KVK. From the eleven block panchayats present in Kannur, Taliparamba, Kalliasseri, Payyanur and Irikkur blocks were selected based on the agro ecological zones of the district and from these four blocks, four Grama panchayats viz, Ezhome, Kankol - Alapadamba, Kadannapalli- Panapuzha, and Mayyil were selected after consulting each block panchayat office. A list of progressive farmers from each Grama Panchayat were collected from successive Krishi Bhavans and thirty farmers each were selected by simple random sampling, The total number of respondents were one hundred and twenty. A well-structured interview schedule was used for collecting the data from the respondents.

\section{Perception of farmers on Innova- tions in Technology Dissemination (ITD) methods}

Perceptions indicate the users view of a technology/method/initiative, which is formed based on his or her previous experiences. (Sivakumar and Sulaiman, 2015). Perception in this case was operationalized as the farmer's opinion towards various innovations in technology dissemination implemented by different agricultural institutions in Kannur district. To measure the perception of farmers, the scale 
developed by Preethi et al.,(2014) with slight modification was used. This scale consists of ten statements measured in a five point continuum namely, Strongly Agree, Agree, Undecided, Disagree and Strongly Disagree.

Table 1.

Scale to Measure Farmers' Opinion towards ITD

\begin{tabular}{|c|c|c|c|c|c|c|}
\hline S1.No. & Statements & SA & $\mathbf{A}$ & UD & DA & SDA \\
\hline 1. & $\begin{array}{l}\text { Innovations in Technology Dissemination(ITD) } \\
\text { methods are more effective than conventional } \\
\text { methods }\end{array}$ & & & & & \\
\hline 2. & $\begin{array}{l}\text { ITD helps farmers to access new technologies } \\
\text { and products easily. }\end{array}$ & & & & & \\
\hline 3. & $\begin{array}{l}\text { Social media play a crucial role in technology } \\
\text { dissemination }\end{array}$ & & & & & \\
\hline 4. & $\begin{array}{l}\text { Group approach of ITD is more effective than } \\
\text { individual approach }\end{array}$ & & & & & \\
\hline 5. & $\begin{array}{l}\text { Innovations using ICT is more effective for } \\
\text { technology dissemination }\end{array}$ & & & & & \\
\hline 6. & $\begin{array}{l}\text { Participative decision making is ensured in } \\
\text { the implementation of the ITD methods }\end{array}$ & & & & & \\
\hline 7. & $\begin{array}{l}\text { Farmers get an opportunity to take leadership } \\
\text { in technology dissemination process. }\end{array}$ & & & & & \\
\hline 8. & $\begin{array}{l}\text { Greater economic prosperity can be achieved } \\
\text { through the ITD methods. }\end{array}$ & & & & & \\
\hline 9. & $\begin{array}{l}\text { Participative skill training helps farmers to } \\
\text { adopt new technologies and methods. }\end{array}$ & & & & & \\
\hline 10. & $\begin{array}{l}\text { Farmers get an opportunity to introduce their } \\
\text { own innovations to the farming community. }\end{array}$ & & & & & \\
\hline
\end{tabular}

Scoring procedure for measuring 1 for strongly Disagree (SDA) perception of farmers are 5 for Strongly Agree (SA), 4 for Agree (A), 3 for Undecided (UD), 2 for Disagree (DA) and

Based on the scores the Perception Index was calculated using the formula Perception Index $(\mathrm{PI})=\frac{\text { Individual subject's score } \mathrm{x} 100}{\text { Total Score }}$ 


\section{FINDINGS AND DISCUSSION}

The data collected were tabulated and inferences were drawn after appropriate statistical analysis. Perception of farmers on ITD methods were categorized into low, medium and high based on mean and standard deviation.

Majority of the respondents had medium level (62.5\%) of perception on ITD methods followed by low level (27.5\%). Only 10 percent of the respondents had high level of perception on ITD methods implemented by Kannur KVK and other agricultural institutionsin Kannurdistrict. Perception index was calculated based on individual statement scores and it is shown in Table 2.

Table 2.

Perception Index (PI)

\begin{tabular}{|c|c|c|}
\hline $\begin{array}{l}\text { S1. } \\
\text { No. }\end{array}$ & Statements & PI \\
\hline 1. & $\begin{array}{l}\text { Innovations in Technology Dissemination(ITD) methods are more } \\
\text { effective than conventional methods }\end{array}$ & 81.16 \\
\hline 2. & ITD helps farmers to access new technologies and products easily. & 81 \\
\hline 3. & Group approach of ITD is more effective than individual approach & 80.5 \\
\hline 4. & $\begin{array}{l}\text { Participative skill training helps farmers to adopt new technologies } \\
\text { and methods. }\end{array}$ & 76.17 \\
\hline 5. & Innovations using ICT is more effective for technology dissemination & 75.5 \\
\hline 6. & $\begin{array}{l}\text { Participative decision making is ensured in the implementation of the } \\
\text { ITD methods }\end{array}$ & 75 \\
\hline 7. & $\begin{array}{l}\text { Greater economic prosperity can be achieved through the ITD } \\
\text { methods. }\end{array}$ & 74.6 \\
\hline 8. & Social media play a crucial role in technology dissemination & 70.33 \\
\hline 9. & $\begin{array}{l}\text { Farmers get an opportunity to take leadership in technology } \\
\text { dissemination process. }\end{array}$ & 68.17 \\
\hline 10. & $\begin{array}{l}\text { Farmers get an opportunity to introduce their own innovations to the } \\
\text { farming community. }\end{array}$ & 61.17 \\
\hline
\end{tabular}


From Table 2, it is observed that the statements viz., 'Innovations in Technology Dissemination (ITD) methods are more effective than conventional methods', 'ITD helps farmers to access new technologies and products easily' and 'Group approach of ITD is more effective than individual approach' were perceived as best by the farmers with perception index of $81.16,81$, and 80.5 respectively. More than half of the farmers opined that latest ICT based farmer oriented technology dissemination methods will be more effective than conventional methods, but majority of them were not aware of the newly introduced methods for technology transfer.

\section{CONCLUSION}

The concept of Innovations in Technology Dissemination (ITD) was initiated as a component of National Agriculture Technology Project (NATP) and it is primarily concerned with transmitting information and knowledge of important agricultural technology from research to farmer. Perception of farmers on Innovations in Technology Dissemination methods implemented by different agricultural institutions in Kannur district was calculated and it shows that majority of the respondents had medium level (62.5\%) of perception on ITD methods followed by low level $(27.5 \%)$. Only 10 percent of the respondents had high level of perception on ITD methods implemented by Kannur KVK and other agricultural institutions in Kannur district.

\section{REFERENCES}

Preethi, M. S., Nataraju. M.S. \& Lakshminarayan, M. T. (2014). Development of a Scale to Measure Perception of Farm Youth towards Agriculture. International Journal of Extension Education, 10, 165-167.

Sivakumar, P.S., \& Sulaiman, V.R. (2015). Extension Research in India: Current Status and Future Strategies. Retrieved from: http://www.g-fras. org / en / forum / 2-all-topics / 829 Extension-Research-in-India-CurrentStatus-Future-Strategies.html 